\title{
Review of Tackling Long-Term Global Energy Problems: The Contribution of Social Science by Daniel Spreng, Thomas Flüeler, David L. Goldblatt and Jürg Minsch (Editors)
}

\author{
Linda Bausch* and Anna Mohr
}

\section{Book details}

Spreng, D, Flüeler, T, Goldblatt, DL and Minsch, J (Editors)

Tackling Long-Term Global Energy Problems: The Contribution of Social Science.

Environment and Policy, Volume 52, Dordrecht, Heidelberg, London, New York: Springer; 2012.

336 pages, ISBN 978-94-007-23332-7

The book calls for the inclusion of social sciences into energy policy research, considering these systems as sociotechnical systems, embedded into society. In the second part, the book presents convincing examples from empirical research, which support a broader inclusion of social science research and its practical implementation into decision-making for energy policies. All examples are presented in a comprehensive way, including field studies on household electricity, emission trading, fossil and renewable energies, which all contributed to Chapter 14 addressing the final lessons learned.

The first chapter outlines the reasons for a marginal participation of social sciences in energy research, where funding is dominated by techno-economic interests. Social science, as a cross-cutting issue, has a concrete role and responsibility in solving energy-related challenges regarding social, economic and ecological problems. Chapter 2 classifies global energy-related challenges in three categories: (1) access and security, (2) climate change and other environmental impacts and (3) economic and social development. Positive contributions of social sciences, which are needed for reflection, analysis and transformative knowledge in the sustainable development of energy policies, are introduced in the third chapter. The second part starts with Chapter

\footnotetext{
* Correspondence: linda.bausch@ufz.de

Department Bioenergie in Kooperation mit dem Department Bioenergiesysteme des Deutschen Biomasseforschungszentrums gemeinnützige $\mathrm{GmbH}$ (DBFZ), UFZ - Helmholtz Zentrum für Umweltforschung, Torgauer Straße 116, Leipzig 04347, Germany
}

4, containing a 10-year analysis of articles published in the journal Energy Policy. Here, the authors identified the broad potential of contributions in social sciences to the field of energy policy, encouraging scientists to publish in relevant journals. An integrative framework for energy transitions in developing countries with the focus on ethical considerations is presented in Chapter 5 on the basis of programmes and policies aiming at facilitating energy transitions. An ethnographic analysis of changing household electricity consumption patterns in India (Chapter 6) relates these developments to political and social changes in the country. Policy recommendations can be derived from gender-specific changes or individual needs, e.g. electric house cooling to enhance climateadapted designs for house building projects. Chapter 7 pays attention to the 'curse of oil' in the context of a fastchanging environment, as Chinese companies are entering the international oil business. This example calls for a changing approach to manage macroeconomic impacts of oil revenues, controlled by feasibility and impact studies, to enhance the opportunities for sustainable development in affected countries. In order to manage environmental pollutants, the economic policy instrument of emission trading was designed. In Chapter 8, the question is asked whether an economic approach for an evaluation of emission trading should be broadened by other disciplines, e.g. to capture ethical topics such as justice. In the following chapter, a critical assessment of the history of wind turbine and biogas technologies is presented in the context of the Danish energy system. Changing expectations and conditions in the sometimes conflicting institutional, regulatory, technologic, political, economic and societal framework are taken into account. In Chapter 10, the carbon dioxide capture and storage technology is assessed against criteria from the governance of radioactive waste. Short-term 'quick-fix' solutions are interpreted beyond the 
background of long-term leakage and carbon lock-in effects. Via a cross-disciplinary methodology approach, the various environmental and societal dimensions of such a technology are evaluated. Chapter 11 gives a contribution to the question of participatory approaches in the field of energy system research. The authors examined conceptually and with the help of concrete examples appropriate participation techniques and research methods in order to reach the goal of collaboration of different actors via an inclusive functional-dynamic approach. The seven invited contributions from Chapters 5 to 11 are analyzed in the following Chapter 12 under the lens of the three challenges presented in Chapter 2. Lessons from these contributions are highlighted and synthesized.

The second part of this book is finalized by Chapter 13, in which the various research perspectives of these studies are pointed out. The contributions are classified according to three perspectives: (1) the number of disciplines involved, (2) the type and scope of participating actors as well as (3) the nature of the research question. In the final Chapter 14 (Part III), a synthesis of the studies of Part II is given and embedded into current findings of social science literature as well as into the overall Agenda for SocialScience Research on Long-term Energy Options project.

Concepts of trans- and interdisciplinary energy research are presented in this book. The value of such concepts and methods is demonstrated and evaluated within the empirical contributions of Part II. It is an important conclusion that the inclusion of social sciences into energy research is essential in order to tackle the upcoming energy challenges in a sustainable way. The book offers opportunities for interdisciplinary students and researchers in energy-related issues. The epistemic community of energy researchers is requested to open up the scope of disciplines, methods and approaches among which newly arising pathways, technologies and concepts are analyzed. Natural scientists and engineers, social scientists, technical professionals and politicians implementing energy policy programmes are likewise addressed by this book's message.

\section{Competing interests}

The authors declare that they have no competing interests.

\section{Authors' contributions}

AM and LB jointly carried out the review and drafted the manuscript. Both authors read and approved the final manuscript.

Received: 6 March 2013 Accepted: 6 March 2013

Published: 20 March 2013

doi:10.1186/2192-0567-3-5

Cite this article as: Bausch and Mohr: Review of Tackling Long-Term Global Energy Problems: The Contribution of Social Science by Daniel Spreng, Thomas Flüeler, David L. Goldblatt and Jürg Minsch (Editors). Energy, Sustainability and Society 2013 3:5.

\section{Submit your manuscript to a SpringerOpen ${ }^{\odot}$ journal and benefit from:}

- Convenient online submission

- Rigorous peer review

- Immediate publication on acceptance

- Open access: articles freely available online

- High visibility within the field

- Retaining the copyright to your article

Submit your next manuscript at $\boldsymbol{\wedge}$ springeropen.com 